\title{
Socio-Economic Status of Fishing Communities in Bangsamoro
}

\section{| Naima G. Pendi |}

\author{
Mindanao State \\ University-Maguindanao, \\ Philippines
}

ngpendi@msumaguindanao edu.ph

\begin{abstract}
The study evaluated the socioeconomic condition of fishermen in the coastal municipalities in Bangsamoro. The respondents of the study were the beneficiaries of the Integrated Livelihood Assistance Program for the fishing communities. The variables included in this study were the demographic profile of the respondents, the technical assistance and livelihood assistance programs of the Bureau of Fisheries and Aquatic Resources. Frequency count, percent, and mean had been used for the description of the variables of the study, likewise, correlation and regression analysis was used to determine the relationship of the variables of the study. Results revealed that the mean age of the respondents is 42.64 years old; having a family size of 6.39; having 21.79 years for the mean years in fishing; and having an average monthly income of P5, 414.70. As to technical assistance, the fisherfolks were seldom given with technical assistance program. Meanwhile, livelihood assistance was given with moderate support in alleviating their socio-economic condition and the development of the fisherfolks. It was also found out that the fisherfolks have somewhat positive knowledge learned, skills acquired, and attitudes towards the assistance programs in alleviating their socio-economic condition and development. Meanwhile, it was also posted that there is a significant correlation between the knowledge, skills acquired, and attitudes of the fisherfolk and the extent of technical and livelihood assistance programs. Moreover, the knowledge learned, skills acquired and attitudes of the fisherfolks significantly influence their fishing activities. KEYWORDS

Socio-economic status; fishing communities; Bangsamoro
\end{abstract}

\section{INTRODUCTION}

Marine fisheries is one of important things in Philippine. There are more than one million livelihoods of Philippines are supported by marine fisheries. The result of maritime is as the biggest of production in that country. As we know marine fishes remain one of the most cost-effective protein sources. So it very helps their livelihood and daily sustenance (David \& Robert, 2020).

In 2017, the Philippines had a population of roughly 103 million, with the mean per capita consumption of fish and fishery products of $40 \mathrm{~kg} /$ year or 109 grams/day with the proportion of fish and fishery products intake to the overall intake at 12 . So, It becomes a main sector that result the stabile income start from fish dish, fishing industry, and others related with the production of marine. Especially for supplying the foods industry that is processed from fish (Chavez, 2021).

The Fishery livelihood program or also known as BFAR is one way to help fishermen in helping the survival of the community and BFAR is expected be able to lead for implementing the programs in order to find the aim of that community. However, the measurement of the ability of BFAR can achieve the result well to accomplish this mandated work is a smart management practice that it must undertake. However, while BFAR has done 
a good job in terms of its training and extension programs, as well as facilitating credit assistance to fishermen, more research is needed to determine the extent to which the livelihood program's components, namely credit assistance, training, and extension, are implemented

Since BFAR program has been existed in 1997 and bring well-being the livelihood from societies. Through some assessments have been done and monitor the progress of that program in the various region of the country. But, after the program was evaluated. It hasn't been conducted in the ARMM. Thus, this evaluative study would help government line agencies, particularly the BFAR to develop appropriate livelihood initiatives that will ameliorate the socio-economic situation of the most disadvantaged segment in our society.

The findings of the study would serve as guiding information of the service providers in their effort to effectively and efficiently implement the technical and livelihood assistance programs to the fishermen. Moreover, the findings of the study would provide vital information to all the implementers on how they can enhance the implementation of their projects, programs, and activities as well as on how they can improve the delivery of services and interventions that will eventually uplift living conditions of the target beneficiaries.

This study would prepare project implementers to consider strategies in addressing the challenges in the implementation. With this humble work, this study may help inspire others deeper for the development of their communities. Students and researchers who will be interested to conduct research related to this study will be benefited. This may contribute to literature regarding public policy, particularly in the implementation process. Finally, the study may unveil data that could be used as a take-off point for other researchers to conduct deeper investigations in the future.

The study seeks to evaluate the socioeconomic condition of fishermen in the coastal municipalities in Bangsamoro. The respondents of the study were the beneficiaries of the Integrated Livelihood Assistance Program for the fishing communities. The variables included in this study were the demographic profile of the respondents, the technical assistance and livelihood assistance programs of BFAR.

\section{RESEARCH METHODS}

This study uses descriptive survey and correctional methods. Because this method is very suitable in use the respondents' demographic profile, the integrated livelihood assistance program and their socioeconomic status was descriptively described. The respondents of this study were 280 BFAR's integrated livelihood Program beneficiaries in the coastal areas of 2 Provinces of Bangsamoro areas in Mainland Mindanao; particularly in the Province of Maguindanao and Lanao del Sur. Multi-stage sampling design had been used in this study. The 2 Regions in Mindanao such as ARMM and SOCCSKSARGEN (Figure 2) has been selected as the study area, in which each Region has 2 sample Provinces, each Province has 2 sample Municipalities and each Municipalities, and 2 Barangays were identified as sampling areas.

\section{RESULTS AND DISCUSSION}

\section{Respondents' Socio-economic Profile}

In general, the mean age of the respondents is 42.64 year old; having a family size of 6.39 ; with the mean educational attainment of primary school (41.04), have 21.79 years for the mean years in fishing; and had an average monthly income of P5, 414.70. 
Assistance Program for the Alleviation of Socio-economic Condition and Development

\section{Technical Assistance}

The result indicated that the respondents have an overall rating on the technical assistance that they seldom given with assistance program. This implies that very few technical assistance programs were being given by the government in alleviating the socio-economic condition and development of the fishermen.

Table 1. Assistance Program for the Alleviation of Socio-economic Condition and Development in terms of Technical Assistance

\begin{tabular}{lcl}
\hline \hline Indicator & Mean & Description \\
\hline 1. House to house visit & 2.56 & Often \\
2. Farm visit & 2.55 & Often \\
3. Demonstration & 2.68 & Often \\
4. Meeting & 2.46 & Often \\
5. Storytelling & 2.42 & Seldom \\
6. Round Table Discussion & 2.51 & Often \\
7. Seminar/workshop & 2.68 & Often \\
8. Lecture series & 1.84 & Seldom \\
9. School on the Air & 2.04 & Seldom \\
10. Community trade fair/exhibits & 2.07 & Seldom \\
\hline Weighted Mean & 2.38 & Seldom \\
\hline \hline Scale Description & & \\
3.50-4.00 Always & & \\
2.50-3.49 Often & & \\
1.50-2.49 Seldom & & \\
1.00-1.49 None & &
\end{tabular}

\section{Livelihood Assistance}

It can be seen in the result that the fishermen respondents were given with full support in terms of the livelihood programs in alleviating their socio-economic condition and development. This implies that the fishermen had enjoyed and were given privileges on livelihood assistance.

Table 2. Assistance Program for the Alleviation of Socio-economic Condition and Development in terms of Livelihood Assistance

\begin{tabular}{lcl}
\hline \hline Indicator & Mean & Description \\
\hline 1. fishing gears & 2.61 & Full support \\
2. none motorized boat & 2.11 & Partial support \\
3. motorized boat & 2.15 & Partial support \\
4. Fish landing facilities & 2.36 & Partial support \\
a. Building & 2.63 & Full support \\
b. Stool & 1.72 & Partial support \\
c. Weighing scale & 2.00 & Partial support \\
5. cold storage facilities & 2.00 & Partial support \\
6. Fish drier & 1.66 & Partial support \\
7. Cash & 2.14 & Partial support \\
\hline Weighted Mean & 2.61 & Full support \\
\hline \hline
\end{tabular}

\begin{tabular}{ll}
\hline \hline Scale & Description \\
$2.50-3.00$ & Full support \\
$1.50-2.49$ & Partial supports \\
$1.00-1.49$ & No support
\end{tabular}




\section{Knowledge Learned}

It was found out that the assistance program in terms of knowledge learned in alleviating the socio-economic condition and development of the fisherfolks was moderately effective. This is an indication that through the assistance programs, the fishermen have developed awareness and knowledge on coastal resources management practices and were equipped with formation of knowledge related to livelihood programs and coastal resources managements.

Table 3. Assistance Program for the Alleviation of Socio-economic Condition and Development in terms of Knowledge Learned

\begin{tabular}{|c|c|c|c|}
\hline \multicolumn{2}{|c|}{ Indicator } & Mean & Description \\
\hline \multicolumn{2}{|c|}{$\begin{array}{l}\text { 1. Formation of knowledge related to livelihood programs } \\
\text { and coastal resources management }\end{array}$} & 3.37 & Moderately effective \\
\hline \multicolumn{2}{|c|}{ 2. Coastal resources management practices } & 3.91 & Effective \\
\hline \multicolumn{2}{|c|}{ 3. Fishery rules and regulations } & 3.73 & Effective \\
\hline \multicolumn{2}{|c|}{ 4. Credit assistance procedures } & 2.34 & Moderately effective \\
\hline \multicolumn{4}{|c|}{ B. Production Technology } \\
\hline \multicolumn{2}{|c|}{ 1. Floating fish cages } & 3.59 & Effective \\
\hline \multicolumn{2}{|c|}{ 2. Fish pens } & 2.90 & Moderately effective \\
\hline \multicolumn{2}{|c|}{ 3. Seaweeds farming } & 3.50 & Effective \\
\hline \multicolumn{4}{|c|}{ 5. Fishing gears construction } \\
\hline \multicolumn{2}{|c|}{ a. Handlines } & 3.46 & Moderately effective \\
\hline \multicolumn{2}{|c|}{ b. Gill nets } & 3.67 & Effective \\
\hline \multicolumn{2}{|c|}{ c. Pots and traps } & 3.49 & Moderately effective \\
\hline \multirow{2}{*}{\multicolumn{2}{|c|}{$\begin{array}{l}\text { d. Fish aggregating device (payao) } \\
\text { Weighted Mean }\end{array}$}} & 3.10 & Moderately effective \\
\hline & & \multicolumn{2}{|c|}{$\begin{array}{ll}\text { 3.37 } & \text { Moderately effective } \\
\end{array}$} \\
\hline Scale & \multirow{2}{*}{\multicolumn{3}{|c|}{$\begin{array}{l}\text { Description Interpretation } \\
\text { Very Effective - If the knowledge and skills acquired under the program is } 81-100 \% \\
\text { effective in your area that support. }\end{array}$}} \\
\hline $4.50-5.00$ & & & \\
\hline $3.50-4.49$ & \multicolumn{3}{|c|}{$\begin{array}{l}\text { Effective - If the knowledge and skills acquired under the program is } 61-80 \% \\
\text { effective in your area that supports socio-economic development }\end{array}$} \\
\hline $2.50-3.49$ & \multicolumn{3}{|c|}{$\begin{array}{l}\text { Moderately Effective - If the knowledge and skills acquired under the program is } \\
40-60 \% \text { effective in your area that supports socio-economic development }\end{array}$} \\
\hline $1.50-2.49$ & \multicolumn{3}{|c|}{$\begin{array}{l}\text { Less Effective - If the knowledge and skills acquired under the program is } 21-40 \% \\
\text { effective in your area that supports socio-economic development. }\end{array}$} \\
\hline $1.00-1.49$ & \multicolumn{3}{|c|}{$\begin{array}{l}\text { Not Effective - If the knowledge and skills acquired under the program is } 10-20 \% \\
\text { effective in your area that supports socio-economic development. }\end{array}$} \\
\hline
\end{tabular}

Skills Acquired

It can be noted that the fishermen somewhat acquired skills through the assistance programs in alleviating their socio-economic condition and development. This is an indication that these assistance programs were somewhat have been helpful to the fisherfolks in acquiring skills in terms of the best fishing management practices.

Table 4. Assistance Program for the Alleviation of Socio-economic Condition and Development in terms Skills Acquired

\begin{tabular}{llcl}
\hline \hline Indicator & Mean & Description \\
\hline 1. & Floating fish cages & 3.37 & Moderately agree \\
2. Seaweeds farming & 3.84 & Agree \\
3. Fish pen & 3.67 & Agree \\
4. Fishing gear construction & &
\end{tabular}



a. Handlines
b. Gill nets
c. Pots and traps
d. Fish aggregating device (payao)

5. Crab fattening

6. Fish processing such as:

\begin{tabular}{lll} 
a. Drying & 3.60 & Agree \\
b. Canning & 3.41 & Moderately agree \\
c. Fish smoking & 3.09 & Moderately agree \\
\hline Weighted Mean & 3.34 & Moderately agree \\
\hline \hline
\end{tabular}

It can be gleaned that the fisherfolks have somewhat positive attitudes towards the assistance programs in alleviating their socio-economic condition and development. This implies that the fisherfolks were somewhat participating in the community activities for the rehabilitation, conservation, protection, and management of coastal fishery resources.

Table 5. Attitudes of the fisherfolks on the assistance programs in alleviating the socioeconomic condition and development.

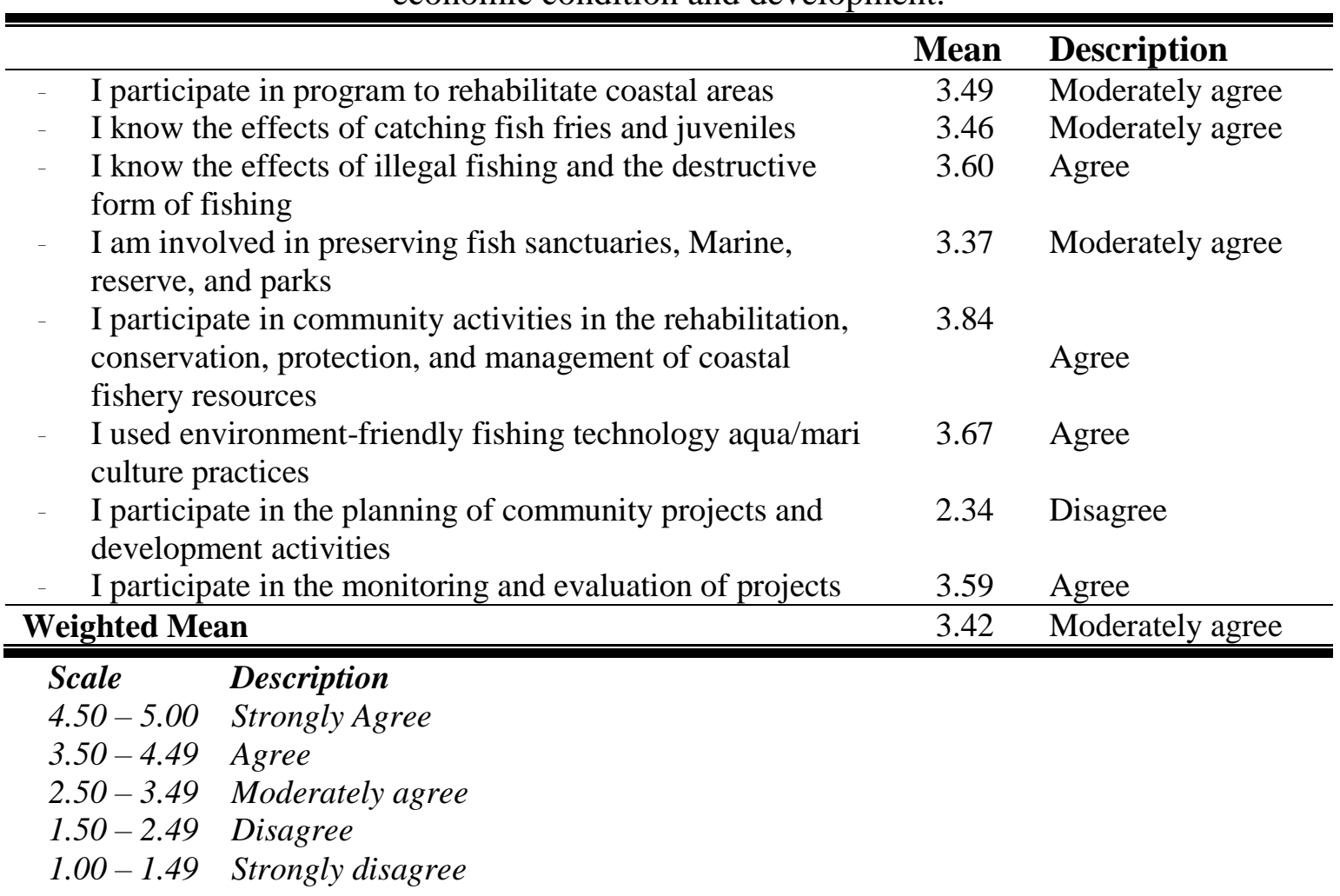

Relationship between Each of the Knowledge, Skills and attitudes And the Extent of Technical and Livelihood Assistance Programs

As presented in table 6, technical assistance was found to be negative but significant correlation with the knowledge, skills acquired and attitudes of the fisherfolk. This relationship was inversely proportional. This implies that the decrease on the technical assistance given to the fisherfolks, it will gradually cause a decrease on their knowledge, skills acquired and attitudes. Meanwhile, livelihood assistance revealed significant association with the knowledge, skills acquired and attitudes of the fisherfolk. This shows a direct proportional relationship between livelihood assistance and the knowledge, skills 
acquired and attitudes of the fisherfolk. This implies that the higher the livelihood assistance extended to the fisherfolks, a corresponding increase of the knowledge, skills acquired and attitudes of the fisherfolk is expected to occur.

Table 6. Relationship between each of the knowledge, skills and attitudes and the extent of technical and livelihood assistance programs

\begin{tabular}{|c|c|c|c|c|c|}
\hline \multirow{2}{*}{$\begin{array}{l}\text { Spearman's } \\
\text { rho }\end{array}$} & \multirow[b]{2}{*}{ Economic Assistance } & \multirow[b]{2}{*}{$\begin{array}{l}\text { Correlation } \\
\text { Coefficient }\end{array}$} & \multicolumn{3}{|c|}{ Knowledge SkillsAquired Attiturde } \\
\hline & & & .088 & .091 & $.123^{*}$ \\
\hline & & Sig. (2-tailed) & .143 & .126 & .039 \\
\hline & & $\mathrm{N}$ & 281 & 281 & 281 \\
\hline & Technical Assistance & $\begin{array}{l}\text { Correlation } \\
\text { Coefficient }\end{array}$ & $-.382^{* *}$ & $-.377^{* *}$ & $-.385^{* *}$ \\
\hline & & Sig. (2-tailed) & .000 & .000 & .000 \\
\hline & & $\mathrm{N}$ & 281 & 281 & 281 \\
\hline & Livelihood Assistance & $\begin{array}{l}\text { Correlation } \\
\text { Coefficient }\end{array}$ & $.580^{* * *}$ & $.581^{* *}$ & $.563^{* *}$ \\
\hline & & Sig. (2-tailed) & .000 & .000 & .000 \\
\hline & & $\mathrm{N}$ & 281 & 281 & 281 \\
\hline
\end{tabular}

** Highly significant

Influence of Assistance Given on the Knowledge Gain by the Respondents on their Fishing Activities

As posted in table 7, technical assistance significantly contributed to the knowledge gain by the respondents on their fishing activities. This connotes that for every decrease in the technical assistance, there would be a corresponding decreased on the knowledge gain by the fisherfolks. Further, livelihood assistance was a significant predictor on the knowledge gain by the fisherfolks.

Table 7. Influence of Assistance given on the knowledge gained by the respondents on their fishing activities

\begin{tabular}{|c|c|c|c|c|c|c|}
\hline & & $\begin{array}{r}\text { Unstand } \\
\text { Coeffi }\end{array}$ & $\begin{array}{l}\text { ardized } \\
\text { ients }\end{array}$ & $\begin{array}{l}\text { Standardized } \\
\text { Coefficients }\end{array}$ & & \\
\hline & & $\mathrm{B}$ & Std. Error & Beta & $\mathbf{t}$ & Sig. \\
\hline 1 & (Constant) & 4.067 & .961 & & 4.234 & .000 \\
\hline & EconomicAssistance & -.230 & .202 & -.055 & -1.138 & .256 \\
\hline & TechnicalAssistance & -1.396 & .213 & -.317 & $-6.570 * *$ & .000 \\
\hline & LivelihoodAssistance & 1.599 & .152 & .507 & $10.528 * *$ & .000 \\
\hline & & & & & & \\
\hline
\end{tabular}

Influence of Assistance Given on the Skills Acquired by the Respondents on their Fishing Activities

Results revealed that technical assistance was found to be negative but significantly contributed to the skills acquired gain by the respondents on their fishing activities. This connotes that for every decrease in the technical assistance, there would be a corresponding 
decreased on the skills acquired by the fisherfolks. Further, livelihood assistance was a significant predictor on the skills acquired by the fisherfolks.

Table 8. Influence of Assistance given on the skills acquired by the respondents on their fishing activities.

\begin{tabular}{|c|c|c|c|c|c|c|}
\hline \multirow{2}{*}{\multicolumn{2}{|c|}{ Model }} & \multicolumn{2}{|c|}{$\begin{array}{l}\text { Unstandardized } \\
\text { Coefficients }\end{array}$} & \multirow{2}{*}{$\begin{array}{c}\text { Standardized } \\
\text { Coefficients } \\
\text { Beta }\end{array}$} & \multirow[b]{2}{*}{$\mathbf{t}$} & \multirow[b]{2}{*}{ Sig. } \\
\hline & & $\mathrm{B}$ & Std. Error & & & \\
\hline \multirow[t]{4}{*}{1} & (Constant) & 4.151 & 1.010 & & 4.112 & .000 \\
\hline & EconomicAssistance & -.232 & .213 & -.053 & -1.092 & .276 \\
\hline & TechnicalAssistance & -1.488 & .223 & -.322 & $-6.663 * *$ & .000 \\
\hline & LivelihoodAssistance & 1.649 & .160 & .499 & $10.333 * *$ & .000 \\
\hline
\end{tabular}

$\mathrm{R}^{2}=0.377$

$\mathrm{F}=55.756^{* *}$

Prob $=0.000$

Influence of Assistance Given on the Attitudes of the Respondents in their Fishing Activities

Results revealed that assistance given to fisherfolks significantly influences their attitudes on their fishing activities. This connotes that whatever assistance was given to the fisherfolks, would significantly be contributed to their attitudes.

Table 9. Influence of Assistance given on the attitudes of the respondents in their fishing activities.

\begin{tabular}{|c|c|c|c|c|c|c|}
\hline \multirow{2}{*}{\multicolumn{2}{|c|}{ Model }} & \multicolumn{2}{|c|}{$\begin{array}{l}\text { Unstandardized } \\
\text { Coefficients }\end{array}$} & \multirow{2}{*}{$\begin{array}{c}\text { Standardized } \\
\text { Coefficients } \\
\text { Beta }\end{array}$} & \multirow[b]{2}{*}{$\mathbf{t}$} & \multirow[b]{2}{*}{ Sig. } \\
\hline & & $\mathrm{B}$ & Std. Error & & & \\
\hline \multirow[t]{4}{*}{1} & (Constant) & 3.921 & .897 & & 4.370 & .000 \\
\hline & EconomicAssistance & -.099 & .189 & -.025 & -.524 & .601 \\
\hline & TechnicalAssistance & -1.386 & .199 & -.334 & -6.983 & .000 \\
\hline & LivelihoodAssistance & 1.469 & .142 & .495 & 10.352 & .000 \\
\hline
\end{tabular}

$\mathrm{R}^{2}=0.388$

$\mathrm{F}=58.454 * *$

Prob $=0.00$

Influence of the Livelihood Assistance Program like Fishing Gears, Fish Landing Facility, Cold Storage House, Fish Drier with the Socioeconomic Condition of the Respondents in terms of Income

Table 10. Influence of the livelihood assistance program like; fishing gears, fish landing facility, cold storage house, fish drier with the socio-economic condition of the respondents in terms of income

\begin{tabular}{|c|c|c|c|c|c|}
\hline \multirow[b]{2}{*}{ Model } & \multicolumn{2}{|c|}{$\begin{array}{l}\text { Unstandardized } \\
\text { Coefficients }\end{array}$} & \multirow{2}{*}{$\begin{array}{c}\text { Standardized } \\
\text { Coefficients } \\
\text { Beta }\end{array}$} & \multirow[b]{2}{*}{$\mathbf{t}$} & \multirow[b]{2}{*}{ Sig. } \\
\hline & $\mathrm{B}$ & Std. Error & & & \\
\hline 1 (Constant) & 3899.89 & 1903.698 & & 2.049 & .041 \\
\hline fishing gears & 497.65 & 396.572 & .077 & 1.255 & .211 \\
\hline none motorized boat & 107.60 & 375.862 & .019 & .286 & .775 \\
\hline motorized boat & 289.12 & 471.683 & .046 & .613 & .540 \\
\hline Fish landing facilities & 183.64 & 148.386 & .076 & 1.238 & .217 \\
\hline
\end{tabular}




\begin{tabular}{|c|c|c|c|c|c|}
\hline cold storage facilities & 237.04 & 694.434 & .029 & .341 & .733 \\
\hline Fish drier & 38.36 & 776.380 & .005 & .049 & .961 \\
\hline Cash & -986.88 & 761.015 & -.108 & -1.297 & .196 \\
\hline
\end{tabular}

As shown in Table 10, none of the variables was a significant predictor of socio-economic condition of the respondents in terms of income. Statistically, only 29 percent of the socioeconomic condition can be attributed to livelihood assistance, while 71 percent can be explained by other variables excluded in the study.

\section{CONCLUSION}

The fisherfolks have somewhat positive knowledge learned, skills acquired and attitudes towards the assistance programs in alleviating their socio-economic condition and development. Meanwhile, it was also posted that there is a significant correlation between the knowledge, skills acquired and attitudes of the fisherfolk and the extent of technical and livelihood assistance programs. Moreover, the knowledge learned, skills acquired and attitudes of the fisherfolks significantly influence their fishing activities. In addition, livelihood programs do not significantly influence the socio-economic condition of the respondents in terms of income.

\section{REFERENCES}

Chavez, Leilani. (2021). Philippine artisanal fishermen cry for help as illegal fishing empties municipal waters. https://pcij.org/article/6785/philippine-fishermen-cry-help-illegalfishing-empties-municipal-waters

Suh David \& Pomeroy Robert (2020). Projected Economic Impact of Climate Change on Marine Capture Fisheries in the Philippines. Frontiers in Marine Science vol.7, 2020, pages 232. https://www.frontiersin.org/article/10.3389/fmars.2020.00232. doi10.3389/fmars.2020.00232 ISSN=2296-7745

BFAR Administrative Circular Oder No. 1 Series of 2019 and PSA approved memorandum of Correcting Nomenclature of Indian oil sardines to Bali sardinella dated 03 July 2019. https://psa.gov.ph/content/fisheries-situation-report-january-december-2020 